\title{
Expansion of CMA/'s support for health promotion and disease prevention
}

\section{Noni MacDonald MD, Erica Weir MD, David Patrick MD, Louise Potvin PhD, Jeff Scott MD}

Among the functions of public health are health protection (e.g., food and water safety, basic sanitation), disease and injury prevention (including vaccinations and outbreak management), population health assessment; disease and risk factor surveillance; and health promotion. ${ }^{1}$

I n the early 2oth century, public health was well recognized as a major factor in ensuring the health of the community. Infectious diseases such as influenza, diphtheria, tuberculosis and polio cut wide swaths through the population, striking fear into the hearts of the afflicted and their families, as well as the physicians providing care. Millions died, including thousands of Canadians who succumbed to the "Spanish flu" (the influenza pandemic of I9I8). Infants and children were particularly affected by diphtheria, gastroenteritis and polio. Bringing many of these killers under control through public health programs was hailed as one of the greatest accomplishments of medicine in the past century. ${ }^{2}$ As illness rates dropped, so did general interest in public health, only to rise again with the development of HIV/AIDS and SARS (severe acute respiratory syndrome), growing concerns about the impact of water and environmental contaminants, weather-related crises such as hurricanes, flooding and ice storms, and rising rates of obesity and other serious health problems. These more recent problems have all presented timely reminders of the importance of Virchow's I848 principles of public health (Box I), ${ }^{2}$ the central role of public health in the health of communities $^{3}$ and the need for practitioners to be well versed in and connected to this area.

Given the important role of public health in maintaining the health and well-being of individuals and populations worldwide, $C M A$ F's public health team sees a need to expand the range and depth of public health coverage in the journal. The public health mission of $C M A J$ now has 3 major foci:

- to provide evidence-based public health information in a user-friendly fashion for practitioners and health care professionals

- to publish high-quality public health and social medicine research articles in a widely read and open-access venue

to provide a forum for the discussion of contentious issues in public health

In fulfilling this mission, we will build on past successes, such as the timely reports and advice on Spanish flu by Boucher ${ }^{4}$ and $\mathrm{McCullough}^{5}$ in $\mathrm{Ig} \mathrm{I} 8$, on tuberculosis chemotherapy by Florey ${ }^{6}$ in 1954 and on the SARS outbreak by Hoey ${ }^{7}$ and Maunder and associates ${ }^{8}$ in May 2003. We are expanding
Box 1: Virchow's principles of public health ${ }^{2}$

- The health of the people is a matter of direct social concern

- Social and economic conditions have an important effect on health and disease, and these relations must be subjected to scientific investigation

- Measures taken to promote health and to combat disease must be social as well as medical

the range of articles (see Box 2) that will appear under the public health rubric in CMAJ. This issue, for example, includes 2 papers on HIV and hepatitis C infection among prison inmates ${ }^{9,10}$ and a related advocacy commentary on this important public health issue. ${ }^{11}$ When crises occur, we will help raise awareness of public health alerts, such as those issued by the Public Health Agency of Canada, using the online resources of e-CMAJ, as well as the print journal. When appropriate, we will also strive to mollify undue public alarm with reason, varied perspectives and timely, high-quality information.

Although some pieces for the public health section will be solicited, we also look forward to receiving unsolicited submissions from those working in the field, in academia and in government. All public health contributions will undergo peer review.

CMAJ is committed to improving health by disseminating knowledge that can be readily applied to practice and by advocating for changes in legislation and in program availability. As a major open-access medical journal, CMAJ can offer wide dissemination of timely research and commentary on issues relevant to the well-being of all. This expansion of the range of formats for public health articles, the breadth of topics to be covered and the size of the audience for this material signals $C M A F$ s commitment to the area and our recognition of its importance for the practitioners of today and for the health and well-being of Canadians for tomorrow.

CMAJ Public Health Advisory Group: Noni MacDonald, Section Editor, Public Health, CMAJ, and Division of Infectious Diseases, IWK Health Centre, Halifax, NS; Erica Weir, Associate Medical Officer of Health for York Region, Newmarket, Ont., and Department of Community Health and Epidemiology, Queen's University, Kingston, Ont.; David Patrick, Department of Epidemiology, British Columbia Centre for Disease Control, Vancouver, BC; Louise Potvin, Department of Preventive Medicine, Université de Montréal, Montréal, Que.; and Jeff Scott, Chief Medical Officer of Health, Province of Nova Scotia, and Department of Paediatrics, IWK Health Centre, Halifax, NS. 


\section{Box 2: Public health in CMAJ}

\section{Columns}

Health promotion and disease prevention

- Discussing public health topics of relevance to practice

- Aimed at front-line practitioners and health care providers Advice from your doctor

- Discussing public health topics of concern to the population

- Aimed at patients and their families

\section{Commentaries}

Synopses

- Synopses of evidence-based guidelines, published in CMAJ and elsewhere, that deal with public health issues

\section{Brief reports}

- Reports of current public health problems, with information on epidemiology, diagnosis, management and interventions

Advocacy

- Commentaries on public health topics, with a focus on the need for changes in legislation, regulation, practice and behaviour

Consequences

- Analyses of the public health consequences of legislation, product recalls, health policy and other factors

\section{Research}

\section{Narrative reviews}

\section{Systematic reviews}

\section{Alerts}

- Brief, timely information on important public health topics, with appropriate links to more detailed information
Competing interests: None declared.

Contributors: Noni MacDonald, David Patrick, Louise Potvin and Jeff Scott drafted the background document on which this article is based. Erica Weir contributed substantially to the critical revision of the final draft. All of the authors reviewed, commented on and accepted the drafts, including the final draft.

\section{REFERENCES}

I. National Advisory Committee on SARS and Public Health. Learning from SARS renewal of public health in Canada - executive summary. Ottawa: Public Health Agency of Canada; updated 2004 Nov 8. Available: www.phac-aspc.gc.ca/publicat /sars-sras/naylor/exec_e.html (accessed 2007 Jun I9).

2. Waitzkin H. One and a half centuries of forgetting and rediscovering: Virchow's lasting contributions to social medicine. Soc Med 2006;I:5-Io. Available: http://journals .sfu.ca/socialmedicine/index.php/socialmedicine/article/viewPDFInterstitial/6/6 (accessed 2007 Jun I9).

3. The Ottawa charter for health promotion. Geneva: World Health Organization I986. WHO/HPR/HEP/95.I. Available: www.who.int/hpr/NPH/docs/ottawa _charter_hp.pdf (accessed 2007 Jun 25).

4. Boucher S. The epidemic of influenza. CMAJ I918;8:1087-92.

5. McCullough JWS. The control of influenza in Ontario. CMAJ I918;8:1084-6.

6. Florey H. The chemotherapy of tuberculosis. CMAJ I954;7I:4I7-2I.

7. SARS: the struggle for containment [editorial]. CMAJ 2003;I68:1229.

8. Maunder R, Hunter J, Vincent L, et al. The immediate psychological and occupational impact of the 2003 SARS outbreak in a teaching hospital. CMAJ 2003;I68: I245-5I.

9. Poulin C, Alary M, Lambert G, et al. Prevalence of HIV and hepatitis C virus infections among inmates of Quebec provincial prisons. CMAJ 2007;177:252-6.

Io. Calzavara L, Ramuscak N, Burchell AN, et al. Prevalence of HIV and hepatitis C virus infections among inmates of Ontario remand facilities. CMAJ 2007;177:257-6I.

II. Elliott R. Deadly disregard: government refusal to implement evidence-based measures to prevent HIV and hepatitis $\mathrm{C}$ virus infections in prisons [editorial]. CMAJ 2007;177:262-4.

Correspondence to: Dr. Noni MacDonald, IWK Health Centre, 5850/5980 University Ave., PO Box 9700, Halifax NS B3K 6R8; noni.macdonald@dal.ca

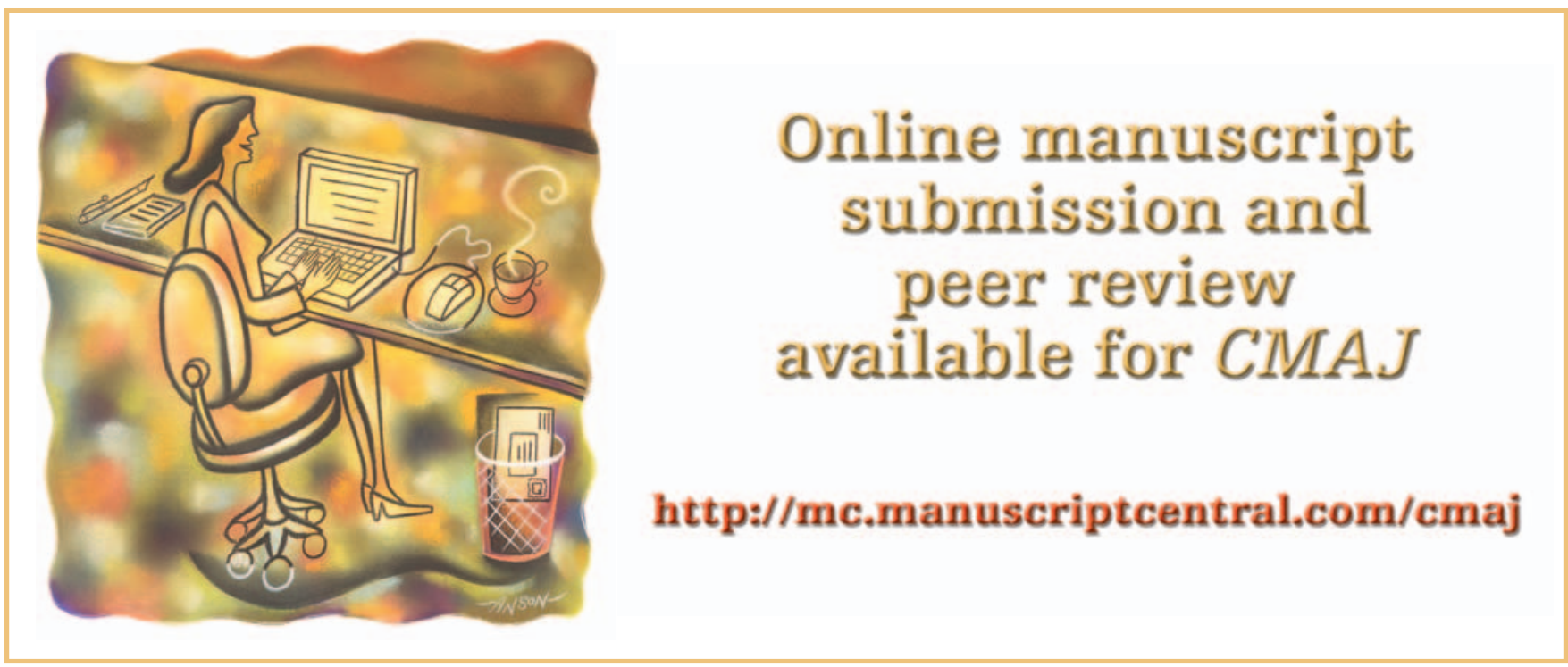

